Sains Malaysiana 50(7)(2021): 1971-1985

http://doi.org/10.17576/jsm-2021-5007-12

\title{
Tualang Honey Supplementation Improves Inflammatory and Bone Markers among Postmenopausal Breast Cancer Patients: A Randomised Controlled Trial
}

(Tambahan Madu Tualang Menambah Baik Penanda Radang dan Tulang dalam Kalangan Pesakit Kanser Payudara Pasca-putus Haid: Suatu Ujian Rawak Terkawal)

\author{
ZAIDA ZAKARIA, WAN ZURAIDA WAN AB HAMID \& MAHANEEM MOHAMED*
}

\begin{abstract}
Honey is traditionally used among breast cancer patients in Malaysia with the belief that it can improve the overall health. Therefore, this study aims to determine the effects of Tualang honey supplementation on levels of inflammatory markers, bone markers and oestradiol among postmenopausal breast cancer patients. Seventy-two patients on anastrozole were recruited and randomly divided into two groups ( $n=36 / g r o u p$, with or without $20 \mathrm{~g} /$ day of Tualang honey for 12 weeks). Levels of interleukin-1 beta (IL-1 $\beta)$, tumour necrosis factor alpha (TNF- $\alpha)$ and carboxy-terminal crosslinked telopeptide of type 1 collagen (CTX) at post-intervention with anastrozole, increased significantly compared to their corresponding levels at pre-intervention. Meanwhile, at post-intervention with anastrozole +honey, procollagen type 1 amino-terminal propeptide level increased significantly, CTX level decreased significantly, with no change in inflammatory markers compared to their pre-intervention levels. In conclusion, Tualang honey supplementation prevented the increased inflammation, reduced bone resorption and increased bone formation without changes in oestradiol level.
\end{abstract} Keywords: Breast cancer; honey; inflammatory marker; oestradiol; postmenopausal

\section{ABSTRAK}

Madu secara tradisinya digunakan dalam kalangan pesakit kanser payudara di Malaysia dengan kepercayaan ia dapat meningkatkan kesihatan secara menyeluruh. Oleh itu, kajian ini bertujuan untuk menentukan kesan tambahan madu Tualang pada tahap penanda keradangan, penanda tulang dan estradiol dalam kalangan pesakit kanser payudara pasca-putus haid. Tujuh puluh dua pesakit yang dirawat dengan anastrozole telah diambil dan dibahagikan secara rawak kepada dua kumpulan ( $n=36 / k u m p u l a n$, dengan atau tanpa $20 \mathrm{~g} /$ hari madu Tualang selama 12 minggu). Tahap interleukin-1 beta (IL-1 $\beta$ ), faktor tumor nekrosis alfa (TNF- $\alpha)$ dan terminal-karboksi paut silang telopeptida kolagen jenis 1 (CTX) pada pasca-intervensi dengan anastrozole telah meningkat dengan ketara berbanding tahap yang sama pada pra-intervensi. Sementara itu, pada pos-intervensi dengan anastrozole+madu, tahap prokolagen aminoterminal propeptida jenis 1 telah meningkat dengan ketara, tahap CTX berkurangan dengan ketara, tanpa perubahan pada penanda radang berbanding pada tahap pra-intervensi. Kesimpulannya, tambahan madu Tualang menghalang keradangan yang meningkat, mengurangkan resorpsi tulang dan meningkatkan pembentukan tulang tanpa perubahan pada tahap estradiol.

Kata kunci: Estradiol; kanser payudara; madu; pasca-putus haid; penanda radang

\section{INTRODUCTION}

Breast cancer continues to be the most frequent type of cancer in women worldwide (Ferlay 2015). A latest statistic update has reported that this disease is still at the top of list for estimated new cancer cases with $30 \%$ cases out of 891,480 estimated new cancer cases from all cancer sites and at the second place with 41,760 (15\%) for the most common reason of cancer death after lung cancer (66,020 deaths) in women (Siegel et al. 2019). In Malaysia, breast cancer is the most common cancer whereby, 7,593 (32\%) estimated new breast cancer cases has been reported which is responsible for 2,894 deaths in 2018 (Bray et al. 
2018). Regardless of various emerging treatment strategies in curing breast cancer, one in 30 Malaysian women is estimated to be at risk of breast cancer in their lifetime (Azizah et al. 2019). Inflammation is a crucial body's immune response towards infection (Philip et al. 2014), however, when the inflammation resolution is disrupted, chronic inflammation occurs and may lead to tissue damage that eventually may turn chronic inflammation to neoplasia (Balkwill \& Mantovani 2001). Studies have been reported that the increased levels of pro-inflammatory markers such as high sensitivity C-reactive protein (hsCRP) (Kaur et al. 2019; Ravishankaran \& Karunanithi 2011), interleukin-6 (IL-6) (Kozlowski \& Zakrzewska 2003), interleukin-1 beta (IL-1 $\beta$ ) (Nicolini et al. 2006), and tumour necrosis factor alpha (TNF- $\alpha$ ) (García-Tuñón et al. 2006), are found in breast cancer patients showing that breast cancer is associated with inflammation. The increases of these pro-inflammatory markers have been linked to breast cancer invasiveness and also have been used as a prognostic factor for breast cancer patients (Pierce et al. 2009).

Apart from classification based on the histological appearance, grade, stage and gene expression, breast cancer can also be categorised based on the cancer cells receptor status by the presence of these three important receptors such as oestrogen receptor (ER), progesterone receptor (PR), and HER2. Breast cancer cells with presence of ER or known as ER+ depend on oestrogen for their growth and need to be treated with drugs to block the oestrogen effects. Whereas, cancer cells which do not possess neither of these three receptors are called triplenegative breast cancer. However, majority of breast cancer patients are $\mathrm{ER}+$, means that the proliferation of breast cancer epithelium is commonly contributed by oestrogen (Russo \& Russo 2006). Since 1977, tamoxifen has been approved to treat advanced hormone receptor-positive breast cancer in postmenopausal women (Henderson 1991; Litherland \& Jackson 1988) and since then, it has been the most widely used hormonal treatment for breast cancer patients. However, many incidences of side effect such as thromboembolic events, vaginal bleeding and increased risk of endometrial carcinoma are reported in patients treated with tamoxifen (Nabholtz et al. 2000; Rosell et al. 2017). Therefore, aromatase inhibitors such as anastrozole and letrozole which block the conversion of adrenal androgens into oestrogen are increasingly being used for the treatment after primary therapy among postmenopausal women (Osborne \& Schiff 2011). It is well known that oestrogen deficiency is the main contributory factor to postmenopausal osteoporosis (Rogers et al. 2002). Postmenopausal women who have breast cancer and treated with anastrozole usually have a low level of oestradiol which tends to increase the risk of osteoporosis, bone loss, fracture risk and decreased bone mineral density (BMD). There are diverse methods accessible for estimating bone loss and identifying women at risk of osteoporosis and fracture such as singleenergy X-ray absorptiometry and dual-energy X-ray absorptiometry (Kenny \& Raisz 2002). Apart from these local measurements, the levels of biomarkers of bone turnover are measured in blood and urine to provide extra information on the bone remodelling process in the entire skeleton has also been done. The bone turnover markers are the combination markers of formation and resorption which represent osteoblast or osteoclast metabolic activity, respectively. Bone Marker Standards Working Group has recommended procollagen type I amino-terminal propeptide (PINP) and carboxy-terminal crosslinked telopeptide of type I collagen (CTX) as specific markers for bone formation and bone resorption, respectively (Vasikaran et al. 2011; Wheater et al. 2013). Previous study has shown a significant increase of CTX level in breast cancer patients received anastrozole for 3 months in comparison with those that received tamoxifen indicating the adverse effect of anastrozole on bone (Banerjee et al. 2005).

Tualang honey is a multi-floral Malaysian wild honey produced by bees (Apis dorsata) (Saba et al. 2013) that has high phenolic content (Kishore et al. 2011), antioxidant (Mohamed et al. 2010), anticancer (Jaganathan \& Mandal 2009), and anti-inflammatory properties (Bashkaran et al. 2011). Previous study has reported that seminal plasma inflammatory markers such as IL-6, TNF- $\alpha$, and IL- 8 are significantly reduced after honey intake at $70 \mathrm{~g}$ daily for 8 weeks among cyclist (Tartibian $\&$ Maleki 2012). The trabecular bone structure in rats supplemented with Tualang honey has shown more improvement compared to rats that received calcium only (Zaid et al. 2012). In addition, the level of oestradiol in postmenopausal women does not change after 4 months of Tualang honey consumption orally at $20 \mathrm{~g}$ /day (Hussain et al. 2012). Previous studies have demonstrated the potential benefit of Tualang honey as an anticancer agent by inducing significant cell death and apoptosis in breast cancer cells in vitro (Fauzi et al. 2011) and also when used alone or in combination with tamoxifen against ER-positive MCF-7 and ER- negative MDA-MB-231 breast cancer cell lines (Yaacob et al. 2013). Decreased levels of diastolic blood pressure and fasting blood glucose have been reported after Tualang honey supplementation for 12 months in postmenopausal women (Ab Wahab et al. 2018). However, the levels of haematological, renal, and liver profiles are within their normal ranges and fasting blood glucose level is not significantly increased after 
12-week of Tualang honey supplementation suggesting that it is safe for postmenopausal breast cancer patients (Zakaria et al. 2018). Herein, we attempt to further evaluate its effects on the levels of inflammatory markers, bone markers and oestradiol in postmenopausal breast cancer patients.

\section{MATERIALS AND METHODS}

\section{HONEY SAMPLE AND ANALYSIS}

Tualang honey used in this study was prepared and evaporated at $40{ }^{\circ} \mathrm{C}$ to achieve $20 \%$ water content before supplied in a sachet form (20 g/sachet) by the Federal Agricultural \& Agro-Based Industry, Kedah, Malaysia. Honey was stored and kept frozen in $-20{ }^{\circ} \mathrm{C}$ for preservation until used. Tualang honey sample was sent to the laboratory at Unipeq Sdn. Bhd. Universiti Kebangsaan Malaysia, Bangi, Selangor, Malaysia and analysed for moisture, 5-hydroxymethyl-2-furfural (HMF) levels, protein, fat, carbohydrate, ash, energy, and sugars. It was also evaluated for its colour intensity (Beretta et al. 2005), pH (Bogdanov 2009), presence of glucose oxidase (Bogdanov 2011), total phenolic content (Singleton et al. 1999), total flavonoid content (Beretta et al. 2005), antiradical activity (DPPH assay) (Aljadi \& Kamaruddin 2004) and antioxidant activity (FRAP assay) (Benzie \& Strain 1999). All measurements were done in triplicate.

\section{STUDY DESIGN}

This was an open-label randomised controlled clinical trial by using a parallel design. The protocol was approved by the Human Ethics Committee, Universiti Sains Malaysia (USM) approval code: USMKK/PPP/ JEPeM [260.3(21)] which complies with the Declaration of Helsinki. This study has also been registered with International Standard Randomised Controlled Trial Number (Clinical Trial Registration: ISRCTN89213965). All patients were required to sign an informed consent form before participating in the trial. Each patient was included in the trial for 12 weeks.

\section{PATIENTS CRITERIA}

A total of 84 postmenopausal breast cancer patients from Oncology Clinic, Hospital Universiti Sains Malaysia (Hospital USM) diagnosed with breast cancer stages I, II, and III, with completed surgery, chemotherapy, radiotherapy and on anastrozole were recruited. Only patients with oestrogen receptor $(\mathrm{ER}+)$ positive and/or progesterone receptor $(\mathrm{PR}+)$ positive and had received oral anastrozole at $1 \mathrm{mg}$ /day for at least 2 weeks were eligible for participation. Patients with history of allergy to honey, severe infection, and/or, receiving hormone replacement therapy were excluded because of the potential effect of these factors on the outcomes of interest. This study was conducted from September 2014 until August 2016.

\section{INTERVENTION}

The honey group received $20 \mathrm{~g}$ /day of Tualang honey with $1 \mathrm{mg}$ /day of anastrozole for 12 weeks. The dose of honey was based on the previous studies using honey in postmenopausal woman (Husniati et al. 2013; Hussain et al. 2012) and the dose for anastrozole was based on the study of anastrozole treatment in postmenopausal breast cancer patients (Eastell et al. 2006). Meanwhile, control group received $1 \mathrm{mg}$ /day of anastrozole for 12 weeks. The dose of $20 \mathrm{~g}$ /day was chosen because this dose is equivalent to 1 tablespoon of honey as it is traditionally consumed by the local patients. All patients were advised to take honey without water in the morning at least 30 min prior to meal and to report any adverse events (e.g. allergy) to the researcher. The patient's compliance was monitored by sachet counting and phone call.

\section{BLOOD COLLECTION AND SAMPLE PREPARATION}

A total of $7 \mathrm{~mL}$ fasting venous blood (at least $10 \mathrm{~h}$ fasting) was collected at pre- and post-interventions. Three $\mathrm{mL}$ of blood was transferred into an ethylenediaminetetraacetic acid (EDTA) tube and then centrifuged at $1,000 \times \mathrm{g}$ for 15 min at $4{ }^{\circ} \mathrm{C}$. Plasma was then collected and kept frozen at $-80{ }^{\circ} \mathrm{C}$ for biochemical analysis of plasma pro-inflammatory markers (hsCRP, IL-6, and TNF- $\alpha$ ). Another $2 \mathrm{~mL}$ of blood was collected in the plain tube and was centrifuged at $1,000 \times \mathrm{g}$ for $15 \mathrm{~min}$ after being allowed to clot for $45 \mathrm{~min}$ at room temperature. The serum was then collected and kept frozen at $-80{ }^{\circ} \mathrm{C}$ for biochemical analysis of serum pro-inflammatory marker (IL-1 $\beta$ ) and bone markers (bone resorption marker CTX and bone formation marker P1NP). The remaining $1 \mathrm{~mL}$ blood was transferred in EDTA tube and was sent immediately to BP Clinical Lab for oestradiol level assessment.

\section{DETERMINATION OF INFLAMMATORY AND BONE MARKERS}

Levels of hsCRP, IL-6, TNF $\alpha$, IL-1 $\beta$, CTX and P1NP were assayed using commercial ELISA kits from Cusabio, USA. The assay sensitivity for hsCRP, IL-6, TNF $\alpha$ and IL-1 $\beta$ were $0.156 \mathrm{ng} / \mathrm{mL}, 2.453 \mathrm{pg} / \mathrm{mL}, 1.95 \mathrm{pg} / \mathrm{mL}$ and 31.25 $\mathrm{pg} / \mathrm{mL}$, respectively. The assay sensitivity for CTX and P1NP were $0.156 \mathrm{ng} / \mathrm{mL}$ and $0.005 \mathrm{ng} / \mathrm{mL}$, respectively. The intra- and inter-assay variations for hsCRP, IL-6, TNF $\alpha$, 
IL-1 $\beta$, CTX and P1NP were less than $8.0 \%$ and $10.0 \%$, respectively.

\section{SAMPLE SIZE CALCULATION}

The sample size for each group was calculated using Power and Sample Size Calculation Software version 3.1.2. The assumption of Type I error probability $(p)$ was $5 \%(0.05)$ and the power of the study was $80 \%(0.8)$ for all parameters. The difference in population means for IL-6, CTX, and oestradiol between two groups $(\delta)$ were 3.0, 0.7 and 12, respectively, while within group standard deviation $(\sigma)$ were $3.99,1.45$, and 23.87 , respectively, based on previous studies for IL-6 (Liu et al. 2012), CTX (Bonjour et al. 2013), and oestradiol (Hussain et al. 2012) levels. The ratio of control to the experimental group (m) was standardized at 1 . Considering the $20 \%$ dropout rate, the sample size for each group was 42 patients. However, the final number of patients for each group was 36 after excluding the dropped-out patients.

\section{RANDOMISATION}

Eighthly four eligible patients were randomised into two parallel groups (control and honey groups). Simple randomisation was carried out by the first author using a randomised table created by computer software (Random allocation software version 1.0) with 1:1 allocation ratio.

\section{STATISTICAL ANALYSIS}

All data were analysed using the Statistical Package for Social Science version 22 (International Business
Machines Corporation, North Castle, USA) and $p<0.05$ was considered as statistically significant. All numerical data with normal distribution and homogenous variance were analysed using independent t-test to compare the parameters between two groups and paired t-test was used to compare the parameters within each group. The data were presented as mean (standard deviation). On the other hand, the categorical data were analysed using Pearson Chi-Square or Fisher's exact tests to compare the parameters between groups while McNemar's test was used to compare the parameters within each group and the results were presented as percentage. A one-way analysis of covariance (ANCOVA) was also conducted after adjustment the important confounding factors, such as pre-intervention values which had significant differences between groups, stage of breast cancer, duration on anastrozole and duration of breast cancer.

\section{RESULTS}

\section{HONEY SAMPLE AND ANALYSIS}

Results of the physicochemical properties of Tualang honey used in this study were in comparison with the criteria for quality honey by Codex Alimentarius Commision (1982) are shown in Table 1. Its total phenolic content was $629.70 \mathrm{mg}$ of Gallic acid Eq kg-1, total flavonoid content was $382.22 \mathrm{mg}$ of quercetin Eq $\mathrm{kg}^{-1}$, antiradical activity was $69.31 \%$ inhibition of DPPH radical, and antioxidant activity was $369.74 \mu \mathrm{mol}$ of Fe ${ }^{2+} \mathrm{Eq} \mathrm{L}^{-1}$.

TABLE 1. Physicochemical properties of Tualang honey

\begin{tabular}{lcc}
\hline \multicolumn{1}{c}{ Parameters } & Tualang honey & Criteria for quality honey $^{\mathrm{a}}$ \\
\hline Colour intensity (mAU) & $753.33(11.24)$ & - \\
$\mathrm{pH}$ & $3.7(0.00)$ & $<20$ \\
Moisture (\%) & $16.2(1.08)$ & - \\
Glucose oxidase (Peroxide test) $\mathrm{mg} / \mathrm{L} \mathrm{H}_{2} \mathrm{O}_{2}$ & $0.50(0.00)$ & $<80$ \\
HMF (mg/kg) & $14.62(0.45)$ & - \\
Protein (\%) & $0.48(0.12)$ & - \\
Fat (\%) & $<0.01$ & - \\
Carbohydrate (\%) & $75.12(0.20)$ & $<0.6$ \\
Ash (\%) & $0.23(0.01)$ & - \\
Energy, Kcal (\%) & $1269.67 \mathrm{~kJ}(2.89)$ & - \\
Sugars & & $>60$ \\
$\quad$ Total reducing sugars (\%) & $72.92(0.88)$ & - \\
$\quad$ Fructose (\%) & $37.63(1.06)$ & - \\
$\quad$ Glucose (\%) & $35.29(0.29)$ & - \\
$\quad$ Fructose: Glucose ratio & $1.07(0.04)$ & $<5$ \\
$\quad$ Sucrose (\%) & N.D $(<0.01)$ & - \\
\hline
\end{tabular}

Data are expressed as mean (SD), n=3. mAU, mili-absorbance unit; HMF, 5-hydroxymethyl-2-furfural; N.D, non-detected. (The moisture, HMF, total reducing sugar and

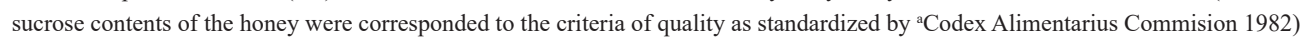




\section{PATIENTS}

Throughout the intervention period, in control group, 6 patients were dropped-out whereby 4 patients were noncompliance with the study schedule. As for honey group, the dropped-out were 6 patients whereby 1 patient had allergy to honey, 3 patients were non-contactable and 2 patients were noncompliance with the study. Therefore, the final numbers of patients were 36 for each study group. Detailed description of the patients' enrolment, randomisation and outcomes are displayed in Figure 1. As shown in Table 2, no significant differences were found between control and honey groups regarding the baseline characteristics of the patients.

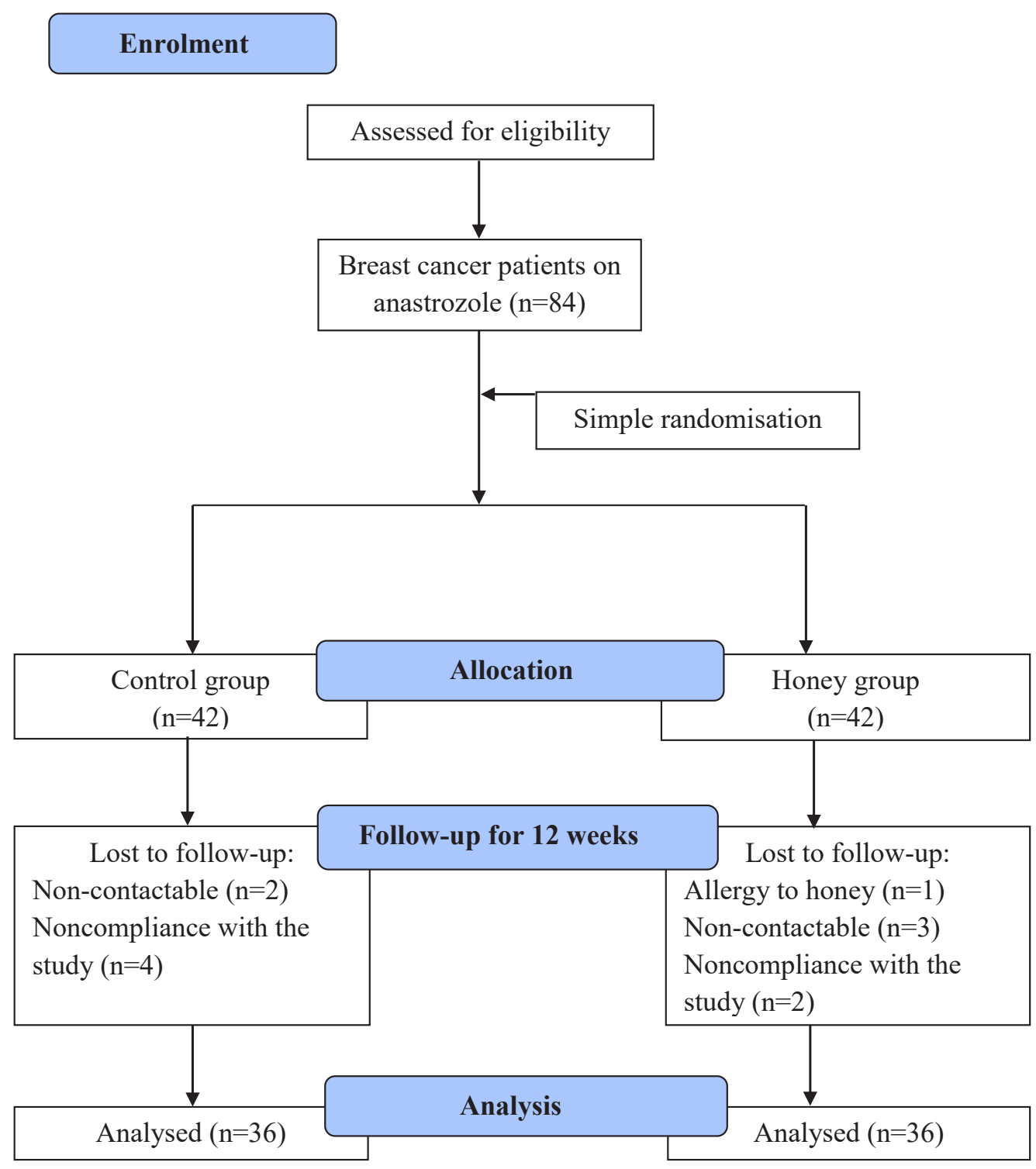

FIGURE 1. Flow chart of the study patients' enrolment, randomisation and outcomes 
TABLE 2. Baseline characteristics of patients

\begin{tabular}{|c|c|c|c|}
\hline \multirow{2}{*}{ Characteristics } & \multicolumn{2}{|c|}{ Groups } & \multirow{2}{*}{$p$-value } \\
\hline & Control $(\mathrm{n}=36)$ & Honey $(\mathrm{n}=36)$ & \\
\hline Age, $\mathrm{yr}^{\mathrm{a}}$ & $59.6(7.84)$ & $56.5(5.94)$ & 0.058 \\
\hline Age at diagnosis, $\mathrm{yr}^{\mathrm{a}}$ & $55.8(7.75)$ & $53.3(5.73)$ & 0.124 \\
\hline Weight, $\mathrm{kg}^{\mathrm{a}}$ & $64.6(12.14)$ & $64.4(13.85)$ & 0.971 \\
\hline BMI, $\mathrm{kg} / \mathrm{m}^{2 \mathrm{a}}$ & $27.0(4.41)$ & $27.0(5.81)$ & 0.977 \\
\hline \multicolumn{4}{|l|}{ Level of education ${ }^{\mathrm{a}}$} \\
\hline Primary & $4(11.1 \%)$ & $2(5.6 \%)$ & \\
\hline Secondary & $11(30.6 \%)$ & $4(11.1 \%)$ & 0.063 \\
\hline Tertiary & $21(58.3 \%)$ & $30(83.3 \%)$ & \\
\hline \multicolumn{4}{|l|}{ Ethnic $^{c}$} \\
\hline Malay & $30(83.3 \%)$ & $35(97.2 \%)$ & \multirow{2}{*}{0.107} \\
\hline Non Malay & $6(16.7 \%)$ & $1(2.8 \%)$ & \\
\hline \multicolumn{4}{|l|}{ Stage of breast cancer ${ }^{\mathrm{b}}$} \\
\hline I & $5(16.7 \%)$ & $5(11.1 \%)$ & \\
\hline II & $21(58.3 \%)$ & $21(58.3 \%)$ & 0.741 \\
\hline III & $10(25.0 \%)$ & $10(30.6 \%)$ & \\
\hline Duration on anastrozole (month) & $14.72(12.41)$ & $13.22(13.60)$ & 0.627 \\
\hline Duration of breast cancer (year) & $3.97(4.86)$ & $3.75(3.27)$ & 0.821 \\
\hline
\end{tabular}

Data are presented as n (\%) except for age, age at diagnosis, weight, BMI, duration on anastrozole, and duration of breast cancer which are presented as mean (SD). a Independent t-test

${ }^{\mathrm{b}}$ Chi-square test,

${ }^{c}$ Fisher Exact test

\section{INFLAMMATORY MARKERS}

The levels of inflammatory markers at pre and postinterventions are presented in Table 3. At pre-intervention, the level of IL-6 in honey group was significantly higher than control group. No significant differences were found for other inflammatory markers between the two groups at pre- and post-interventions even after performing ANCOVA test and with controlling their confounding factors. In control group, the levels of TNF- $\alpha$ and IL- $1 \beta$ were significantly higher at post-intervention than at pre-intervention. However, in honey group, there were no significant differences for all the inflammatory markers between pre and post-interventions. 
TABLE 3. Inflammatory markers levels at pre- and post-interventions

\begin{tabular}{|c|c|c|c|c|c|c|}
\hline \multirow[b]{2}{*}{ Characteristics } & \multirow{2}{*}{$\begin{array}{l}\text { Pre-intervention } \\
\qquad(\mathrm{n}=36) \\
\text { Mean (SD) }\end{array}$} & \multirow{2}{*}{$\begin{array}{c}\text { Post- } \\
\text { intervention } \\
(\mathrm{n}=36) \\
\text { Mean (SD) }\end{array}$} & \multicolumn{4}{|c|}{$\begin{array}{l}\text { Post-intervention }^{\mathrm{c}} \\
\qquad(\mathrm{n}=36)\end{array}$} \\
\hline & & & $\begin{array}{l}\text { Adjusted mean } \\
\quad(95 \% \mathrm{CI})^{\mathrm{c}}\end{array}$ & $\begin{array}{l}\text { Adjusted mean } \\
\text { difference } \\
(95 \% \mathrm{CI})^{\mathrm{c}}\end{array}$ & F-stat ${ }^{\mathrm{c}}$ & $p$-value ${ }^{\mathrm{c}}$ \\
\hline \multicolumn{7}{|l|}{ hsCRP $(\mu \mathrm{g} / \mathrm{mL})$} \\
\hline Control group & $21.66(11.14)$ & $17.74(10.01)$ & $17.46(13.84,21.07)$ & \multirow[b]{2}{*}{$-1.33(-6.34,3.69)$} & \multirow[b]{2}{*}{0.279} & \multirow[b]{2}{*}{0.599} \\
\hline Honey group & $18.45(11.20)$ & $19.57(11.33)$ & $18.78(15.06,22.51)$ & & & \\
\hline \multicolumn{7}{|l|}{$\begin{array}{l}\text { Interleukin-6 } \\
(\mathrm{pg} / \mathrm{mL})\end{array}$} \\
\hline Control group & $115.02(38.13)$ & $133.43(51.81)$ & $138.63(122.63,154.63)$ & \multirow[b]{2}{*}{$-3.04(-25.55,19.47)$} & \multirow[b]{2}{*}{0.073} & \multirow[b]{2}{*}{0.788} \\
\hline Honey group & $138.95(46.56)^{\mathrm{a}}$ & $138.59(42.32)$ & $141.67(125.31,158.04)$ & & & \\
\hline \multicolumn{7}{|l|}{$\begin{array}{l}\text { Interleukin } 1 \beta \\
(\mathrm{ng} / \mathrm{mL})\end{array}$} \\
\hline Control group & $1.18(0.41)$ & $1.39(0.40)^{\mathrm{b}}$ & $1.37(1.23,1.51)$ & \multirow[b]{2}{*}{$0.19(-0.002,0.38)$} & \multirow[b]{2}{*}{3.896} & \multirow[b]{2}{*}{0.053} \\
\hline Honey group & $1.15(0.38)$ & $1.22(0.42)$ & $1.18(1.04,1.32)$ & & & \\
\hline \multicolumn{7}{|l|}{$\mathrm{TNF}-\alpha(\mathrm{pg} / \mathrm{mL})$} \\
\hline Control group & $74.19(24.11)$ & $83.59(20.16)^{b}$ & $84.31(77.10,91.52)$ & \multirow[b]{2}{*}{$-5.98(-15.99,4.03)$} & \multirow[b]{2}{*}{1.422} & \multirow[b]{2}{*}{0.237} \\
\hline Honey group & $86.23(27.43)$ & $89.58(21.91)$ & $90.29(82.85,97.72)$ & & & \\
\hline
\end{tabular}

SD, standard deviation; CI, confidence interval; F-stat, F-statistic; hsCRP, high sensitivity C-reactive protein; TNF $\alpha$, tumour necrosis factor alpha ${ }^{\mathrm{a}} p<0.05$ compared to control group at pre-intervention (independent $t$-test)

${ }^{b} p<0.05$ compared to control group at pre-intervention (paired $t$-test)

cAnalysis of covariance (ANCOVA) after adjustment for pre-intervention value (significant difference), stage of breast cancer, duration on anastrozole, and duration of breast cancer. All of the assumptions were checked and assumptions met

\section{BONE MARKERS}

At pre-intervention, the level of CTX was significantly lower, whereas the level of P1NP was significantly higher in control group compared to honey group. At post-intervention, no significant differences were found for the levels of CTX and P1NP between both groups. However, at post-intervention, the level of adjusted CTX was significantly higher, whereas the level of adjusted P1NP was significantly lower in control group compared to honey group after performing ANCOVA test with controlling their confounding factors. After 12 weeks, in control group, the level of CTX was significantly higher, whereas the level of P1NP was significantly lower at post-intervention compared to their corresponding levels at pre-intervention. However, in honey group, the level of CTX was significantly lower, whereas the level of P1NP was significantly higher at post-intervention compared their corresponding levels at pre-intervention (Table 4). 
TABLE 4. Bone markers levels at pre and post-interventions

\begin{tabular}{|c|c|c|c|c|c|c|}
\hline \multirow{2}{*}{ Characteristics } & \multirow{2}{*}{$\begin{array}{l}\text { Pre-intervention } \\
\qquad(\mathrm{n}=36) \\
\text { Mean (SD) }\end{array}$} & \multirow{2}{*}{$\begin{array}{l}\text { Post-intervention } \\
\qquad(\mathrm{n}=36) \\
\text { Mean (SD) }\end{array}$} & \multicolumn{4}{|c|}{$\begin{array}{l}\text { Post-intervention }{ }^{\mathrm{c}} \\
\qquad(\mathrm{n}=36)\end{array}$} \\
\hline & & & $\begin{array}{l}\text { Adjusted mean } \\
\quad(95 \% \mathrm{CI})^{\mathrm{c}}\end{array}$ & $\begin{array}{c}\text { Adjusted mean } \\
\text { difference }(95 \% \mathrm{CI})^{\mathrm{c}}\end{array}$ & F-stat ${ }^{\mathrm{c}}$ & $p$-value \\
\hline \multicolumn{7}{|l|}{ CTX (ng/mL) } \\
\hline Control group & $3.45(2.75)^{\mathrm{a}}$ & $4.87(2.39)^{\mathrm{b}}$ & $6.47(5.59,7.35)$ & \multirow[b]{2}{*}{$2.65(1.31,3.99)$} & \multirow[b]{2}{*}{15.59} & \multirow[b]{2}{*}{$<0.001$} \\
\hline Honey group & $8.43(4.15)$ & $5.35(3.72)^{b}$ & $3.82(2.94,4.71)$ & & & \\
\hline \multicolumn{7}{|l|}{ P1NP (ng/mL) } \\
\hline Control group & $18.22(11.01)^{\mathrm{a}}$ & $16.38(11.16)$ & $12.23(9.31,15.16)$ & \multirow{2}{*}{$-7.51(-11.88,-3.15)$} & \multirow{2}{*}{11.79} & \multirow{2}{*}{0.001} \\
\hline Honey group & $8.68(8.40)$ & $15.71(12.85)^{\mathrm{b}}$ & $19.75(16.64,22.85)$ & & & \\
\hline
\end{tabular}

SD, standard deviation; CI, confidence interval; F-stat, F-statistic, CTX, carboxyl-terminal cross-linked telopeptide of type I collagen; P1NP, amino-terminal propeptide of type I procollagen

${ }^{a} p<0.05$ compared to honey group at pre-intervention (independent $t$-test)

${ }^{\mathrm{b}} p<0.05$ compared to its corresponding level at pre-intervention (paired $t$-test)

cAnalysis of covariance after adjustment for pre-intervention value (significant difference), stage of breast cancer, duration on anastrozole, and duration of breast cancer.

All of the assumptions were checked and assumptions met

\section{OESTRADIOL}

In Table 5, the oestradiol levels were grouped as $<36.7$ $\mathrm{pmol} / \mathrm{L}$ (categorised as undetectable level) and $>36.7$ to $88.1 \mathrm{pmol} / \mathrm{L}$ (categorised as detectable but within normal range). At pre-intervention, more patients in honey group had oestradiol level of $<36.7 \mathrm{pmol} / \mathrm{L}$ compared to control group, whereas, more patients in control group had oestradiol level of $>36.7$ to $88.1 \mathrm{pmol} / \mathrm{L}$ compared to honey group. At post-intervention, more patients in honey group had oestradiol level of $<36.7 \mathrm{pmol} / \mathrm{L}$ and oestradiol level of $>36.7$ to $88.1 \mathrm{pmol} / \mathrm{L}$ compared to control group. However, there were no significant differences between groups for the levels of oestradiol at both pre- and post-interventions. In control group, more patients had oestradiol level of $<36.7 \mathrm{pmol} / \mathrm{L}$ at postintervention compared to pre-intervention, whereas more patients had oestradiol level of $>36.7$ to 88.1 $\mathrm{pmol} / \mathrm{L}$ at pre-intervention compared to post-intervention. In honey group, more patients had oestradiol level of $<36.7 \mathrm{pmol} / \mathrm{L}$ at pre-intervention compared to postintervention, whereas, more patients had oestradiol level of $>36.7$ to $88.1 \mathrm{pmol} / \mathrm{L}$ at post-intervention compared to pre-intervention. However, there were no significant change for the levels of oestradiol between pre- and postinterventions for both groups.

TABLE 5. Oestradiol levels at pre and post-interventions

\begin{tabular}{|c|c|c|c|c|}
\hline & \multicolumn{2}{|c|}{$\begin{array}{c}\text { Pre-intervention }(\mathrm{n}=36) \\
\mathrm{n}(\%)\end{array}$} & \multicolumn{2}{|c|}{$\begin{array}{c}\text { Post-intervention }(\mathrm{n}=36) \\
\mathrm{n}(\%)\end{array}$} \\
\hline & $<36.7 \mathrm{pmol} / \mathrm{L}$ & $>36.7$ to $88.1 \mathrm{pmol} / \mathrm{L}$ & $<36.7 \mathrm{pmol} / \mathrm{L}$ & $>36.7$ to $88.1 \mathrm{pmol} / \mathrm{L}$ \\
\hline Control group & $26(72.2 \%)$ & $10(27.8 \%)$ & $28(77.8 \%)$ & $8(22.2 \%)$ \\
\hline Honey group & $29(80.6 \%)$ & $7(19.4 \%)$ & $25(69.4 \%)$ & $11(30.6 \%)$ \\
\hline
\end{tabular}

Data are presented as n (\%)

No significant differences were found between and within groups (Chi-square test and McNemar's test, respectively) 


\section{DISCUSSION}

Physicochemical properties of Tualang honey used in the present study which included moisture, HMF, ash, total reducing sugars, and sucrose levels were found to be within the acceptable values as standardized by the Codex Alimentarius Commision (1982). Its total phenolic and flavonoid contents, antiradical or radical scavenging activity and antioxidant activity were comparable with other types of honey reported in previous studies (Beretta et al. 2005; Bertoncelj et al. 2007; Khalil et al. 2011; Socha et al. 2009). In addition, the total flavonoid content and antioxidant activity of Tualang honey used in this study were also comparable with stingless bee honey (kelulut honey) (Hazirah et al. 2019). Hence, these findings demonstrated that Tualang honey used in the present study is a good quality honey and has good in vitro antioxidant properties which are comparable to other reported types of honey.

Our findings showed increased levels of IL-1 $\beta$ and TNF- $\alpha$ in control group after 12 weeks of study suggesting the presence of increased inflammation in control group. These findings are in agreement with other studies in which there are increased expressions of interleukin-1 family (IL-1 $\alpha$, IL-1 $\beta$ ) (Miller et al. 2000) and TNF- $\alpha$ (Miles et al. 1994) in human breast cancer tissue. The increased IL-1 $\beta$ may suggest the higher risk of breast cancer recurrence and invasiveness as it has positive correlations with these risks (Mettler et al. 2004; Pantschenko et al. 2003). TNF- $\alpha$ is recognised as a major mediator in inflammatory responses, activates $\mathrm{T}$ cells and macrophages, and stimulates the secretion of other inflammatory cytokines (Huang et al. 2011; Yun et al. 2008). The increased TNF- $\alpha$ level in control group may also suggest higher risk of increased lymph node metastasis and tumour stage as these risks have positive relationship with increased circulating TNF- $\alpha$ level in breast cancer patients (Sheen-Chen et al. 1997).

After 12 weeks of $20 \mathrm{~g} /$ day Tualang honey supplementation, we observed no significant changes on hsCRP, IL-6, IL-1 $\beta$, and TNF- $\alpha$, levels. In contrast, however, there are decreased hsCRP levels among smokers (Ghazali et al. 2017) and obese subjects (Yaghoobi et al. 2008) after supplementation of 20 and $70 \mathrm{~g}$ daily of Tualang honey, respectively. Other studies have also reported decreased IL-6 levels in paw tissue of carrageenan-induced inflammation in rats (Hussein et al. 2012) and in road cyclist (Tartibian \& Maleki 2012) after supplementation of 1 or $2 \mathrm{~g} / \mathrm{kg}$ and $70 \mathrm{~g} /$ day of honey, respectively. IL-6 is a major mediator of inflammation and activates signal transducer such as Janus kinase
(JAK). Activated JAK stimulates the activation of transcription 3 (STAT3) which regulates expression of genes mediating proliferation and inhibiting apoptosis, thus causes severe implications in terms of progression towards neoplasia (Leu et al. 2003). Treatment with Manuka honey reduced IL-6 production and STAT3 level (Aryappalli et al. 2017), and later study found that the inhibition of IL-6/ STAT3 signaling pathway is via blockage of IL-6 binding with its receptor (IL-6R $\alpha$ ) by Manuka honey flavonoids (luteolin, quercetin, galangin, pinocembrin, and chrysin) (Aryappalli et al. 2019) in breast cancer cell lines.

There are attenuation of IL- $1 \beta$ and TNF- $\alpha$ levels in paracetamol induced-hepatotoxicity rats (Galal et al. 2012) and in metanil yellow-induced hepatotoxicity rats (Al-Malki \& Sayed 2013) after being treated with honey $(5,10$, and $20 \mathrm{~g} / \mathrm{kg} /$ day and $2.5 \mathrm{mg} / \mathrm{kg} /$ day, respectively). These rather contradictory results may be due to the differences in the durations of study, types of subject used, and doses or types of honey supplemented. However, the unchanged levels of IL- $1 \beta$ and TNF- $\alpha$ after 12 weeks of honey supplementation in this study may suggest that honey can ameliorate the increased IL- $1 \beta$ and TNF- $\alpha$ which were found in control group after 12 weeks of study and might also suggest the anti-inflammatory property of honey. In other studies, the levels of TNF- $\alpha$ and IL- $1 \beta$ have been found to be inhibited in lipopolysaccharideactivated N13 microglial cells after treatment with honey flavonoid extract (Candiracci et al. 2012), and decreased level of TNF- $\alpha$ in inflammation-induced rats are suggested to be contributed by phenolic compounds in honey (Hussein et al. 2012). The inhibition of proinflammatory activities of cyclooxygenase-2 and/or inducible nitric oxide synthase are suggested to be the mechanism of action by the flavonoids (Cho et al. 2004). Hence, it is plausible to suggest that the presence of phenolic compounds in Tualang honey which consists of flavonoids (gallic, benzoic, syringic and trans-cinamic acids) and phenolic acids (kaempferol and catechin) (Khalil et al. 2011), may be accountable for the anti-inflammatory effect of honey in the honey group among postmenopausal breast cancer patients which needs further study to evaluate its exact mechanism of action. In addition, these results may also suggest that honey might have a potential to reduce the rate of breast cancer recurrence (Mettler et al. 2004) and invasiveness (Pantschenko et al. 2003) as well as to decrease lymph node metastasis and tumour stage (Sheen-Chen et al. 1997) which are reported to have positive relationships with the levels of IL- $1 \beta$ and TNF- $\alpha$.

After 12 weeks of study, in control group, CTX level was significantly elevated whereas P1NP level was 
statistically unchanged which may suggest increased bone resorption among postmenopausal breast cancer patients. Elevated bone resorption marker level is usually a sign of decreased BMD that increases risk of fracture and eventually leads to occurrence of osteoporosis (Looker et al. 2000). Our results are in agreement with previous study which has reported that adjuvant anastrozole treatment for 1 year resulted in greater increased CTX level compared to PINP level indicating higher bone loss in comparison with adjuvant tamoxifen in postmenopausal breast cancer women (Eastell et al. 2006). In another study, CTX level is significantly increased following 12 weeks of neoadjuvant anastrozole treatment in postmenopausal breast cancer patients, but not in breast cancer patients treated with tamoxifen (Banerjee et al. 2005). These previous studies have indicated that the level of residual oestrogen in the postmenopausal woman plays a crucial role in regulating BMD as anastrozole inhibits aromatase, an enzyme that converts adrenal androgen into oestrogen. Meanwhile, tamoxifen, on the other hand, acts as a partial oestrogen agonist on bone which can increase BMD and prevent bone loss in postmenopausal women (Love et al. 1994, 1992). In addition, bone loss is also related with increased expression of proinflammatory cytokines such as TNF- $\alpha$, interleukin-1 and IL-6 (Manolagas et al. 2002; Pfeilschifter et al. 2002; Riggs et al. 2002). These proinflammatory cytokines have been demonstrated to stimulate osteoclastic bone resorption (Reddy \& Roodman 1998). Elevation of these cytokines have been indicated to cause increased production of prostaglandin E2, an inflammatory mediator which helps in stimulation of osteoclastic activity (Hughes et al. 1999). Therefore, osteoporosis can be strongly related to inflammation. These previous studies are further supported with the results of the present study in which there were significantly increased TNF- $\alpha$ and IL- $1 \beta$ levels in control group compared to their corresponding pre-intervention levels, and no change in honey group may suggest the anti-inflammatory property of honey.

However, after 12 weeks of honey supplementation in honey group, there were significant reduction of CTX level and significant elevation of P1NP level which may suggest reduced bone loss and increased bone formation among postmenopausal breast cancer patients in honey group. These findings are in line with other study which demonstrates an increased BMD in female ovariectomised rats supplemented with Tualang honey for two weeks (Zaid et al. 2010). Furthermore, ovariectomised rats treated with Tualang honey show better improvement in trabecular bone structure in comparison with ovariectomised rats treated with calcium (Zaid et al. 2012). However, the unchanged level of oestradiol in honey group of the present study may suggest that the concomitant decreased CTX and increased P1NP levels were not through the action of oestradiol on bone. The finding of the non-significant change in oestradiol level is consistent with other studies in postmenopausal women after 4 months of Tualang honey consumption orally at $20 \mathrm{~g}$ /day (Hussain et al. 2012), and in ovariectomised rats given Tualang honey for 2 weeks (Zaid et al. 2010). Breast cancer patients have high levels of oestrogens and oestrogen receptor-mediated bioactivity (Lim et al. 2014). Oestrogen receptor (ER) is located predominantly in the cell nucleus and is constantly shuttling between the nucleus and the cytoplasm in the presence of oestrogen (Dauvois et al. 1993). Oestrogen binds to ER to be dimerized and then translocated into the nuclei. This complex then binds to specific DNA base sequences called oestrogen-response elements (EREs) resulting in transcription and translation in the targeted tissue (Gruber et al. 2002). Honey is one of natural phytoestrogens (Al-Rahbi et al. 2014) that may play a role in modulating endogenous oestrogen and ER. Tualang honey may bind to the ER and disrupts dimerization of the receptor to inhibit ER nuclear localisation (Dauvois et al. 1993). This may be exerted by the oestrogen agonist and antagonist effects of honey which may be attributed to its polyphenols or flavonoids content (Tsiapara et al. 2009). Kaempferol and quercetin have been reported to possess a major role in protection against osteoporosis in postmenopausal rats (Wattel et al. 2003). Therefore, the positive results on bone markers in the present study might be due to the anti-inflammatory and antioxidant properties of this Tualang honey.

\section{STUDY LIMITATION}

Many studies have also highlighted the essential roles of signaling through numerous growth factor receptors in regulating breast cancer progression and metastasis, such as vascular endothelial growth factor receptor (VEGF-R), insulin-like growth factors-1 receptor (IGF-1R), fibroblast growth factor receptor (FGF-R), platelet-derived growth factor receptor (PDGF-R) and epidermal growth factor receptor (EGF-R). All these receptor-signaling pathways are mediated by Src-family kinases (Broman et al. 2004) which also play a critical role in growth and proliferation, angiogenesis and invasion, and metastasis, and physiology of bone turnover and metastasis (Finn 2008). The ability of the cancer cells to promote themselves into metastasis 
and spread into distant tissue is by penetrating surrounding extracellular matrices with the aids from alteration in integrin activity which has been reported to be related with Src kinases (Playford \& Schaller 2004). In addition to cytokine, STAT can also be activated by growth factors such as EGF-R and PDGF-R, and as well as Src kinases (Garcia et al. 2001). Treatment with Manuka honey did not show any inhibitory effect on Src kinases in breast cancer cell lines (Aryappalli et al. 2019). However, it is suggested to also investigate the effect of Tualang honey on Src kinases activity in breast cancer cell lines or animal model to assess its potential role in breast cancer progression and metastasis.

Anastrozole metabolism is mainly consists of hydroxylation of anastrozole by cytochrome P450 3A4 (CYP3A4) enzyme, N-dealkylation, and glucuronidisation (Grimm \& Dyroff 1997). Tualang honey induces CYP3A4 enzyme activity in healthy human volunteers, thus helps in increasing the metabolising capacity of this enzyme (Tushar et al. 2007). Therefore, it is suggested to measure CYP3A4 enzyme activity among breast cancer patients treated with anastrozole to evaluate the possible interaction between honey and anastrozole in future study. Apart from that, previous study has reported the positive interaction between hyperglycaemia and biological behaviour of cancer cells (Duan et al. 2014). We have found that Tualang honey supplementation at $20 \mathrm{~g}$ /day for 12 weeks does not significantly increase the fasting blood glucose level among breast cancer patients (Zakaria et al. 2018). However, blood glucose monitoring is suggested among breast cancer patients with longer consumption of honey.

\section{CONCLUSION}

In conclusion, these findings suggest that Tualang honey supplementation at $20 \mathrm{~g} /$ day among postmenopausal breast cancer patients for 12 weeks prevent the increased inflammation, increased bone formation and reduced bone resorption without changes in oestradiol level. This may suggest the potential use of honey as supplementation among postmenopausal breast cancer patients treated with anastrozole. These beneficial effects are probably through the action of phenolic compounds present in Tualang honey which have antioxidant and antiinflammatory properties. However, further study is warranted to elucidate the exact mechanism of action on these beneficial effects of Tualang honey and monitoring of those parameters including the progression or stage of the disease is recommended for longer honey intake.

\section{ACKNOWLEDGEMENTS}

The authors express their appreciation to the participants and research associates who made it possible to complete this research project, Hospital USM for providing the patients, and also Research University Grant, USM (No. 1001/PPSP/853005) for the funding.

\section{REFERENCES}

Ab Wahab, S.Z., Hussain, N.H.N., Zakaria, R., Kadir, A.A., Mohamed, N., Tohit, N.M., Norhayati, M.N. \& Hassan, I.I. 2018. Long-term effects of honey on cardiovascular parameters and anthropometric measurements of postmenopausal women. Complementary Therapies in Medicine 41: 154-160.

Aljadi, A. \& Kamaruddin, M. 2004. Evaluation of the phenolic contents and antioxidant capacities of two Malaysian floral honeys. Food Chemistry 85(4): 513-518.

Al-Malki, A.L. \& Sayed, A.A.R. 2013. Bees' honey attenuation of metanil-yellow-induced hepatotoxicity in rats. Evidence-based Complementary and Alternative Medicine 2013: 614580.

Al-Rahbi, B., Zakaria, R., Othman, Z., Hassan, A. \& Ahmad, A.H. 2014. Enhancement of BDNF concentration and restoration of the hypothalamic-pituitary-adrenal axis accompany reduced depressive-like behaviour in stressed ovariectomised rats treated with either Tualang honey or estrogen. The Scientific World Journal 2014: Article ID. 310821.

Aryappalli, P., Shabbiri, K., Masad, R.J., Al-Marri, R.H., Haneefa, S.M., Mohamed, Y.A., Arafat, K., Attoub, S., Cabral-Marques, O., Ramadi, K.B., Fernandez-Cabezudo, M.J. \& al-Ramadi, B.K. 2019. Inhibition of tyrosinephosphorylated STAT3 in human breast and lung cancer cells by Manuka honey is mediated by selective antagonism of the IL-6 receptor. International Journal of Molecular Sciences 20(18): 4340 .

Aryappalli, P., Al-Qubaisi, S.S., Attoub, S., George, J.A., Arafat, K., Ramadi, K.B., Mohamed, Y.A., Al-Dhaheri, M.M., AlSbiei, A., Fernandez-Cabezudo, M.J. \& al-Ramadi, B.K. 2017. The IL-6/STAT3 signaling pathway is an early target of Manuka honey-induced suppression of human breast cancer cells. Frontiers in Oncology 7: 167.

Azizah, A.M., Hashimah, B., Nirmal, K., Siti Zubaidah, A.R., Puteri, N.A., Nabihah, A., Sukumaran, R., Balqis, B., Nadia, S.M.R., Sharifah, S.S.S., Rahayu, O., Nur Alham, O. \& Azlina, A.A. 2019. Malaysian National Cancer Registry Report 2012-2016. 5th ed. Putrajaya: Ministry of Health Malaysia.

Balkwill, F. \& Mantovani, A. 2001. Inflammation and cancer: Back to Virchow? Lancet 357(9255): 539-545.

Banerjee, S., Smith, I.E., Folkerd, L., Iqbal, J., Barker, P. \& Dowsett, M. 2005. Comparative effects of anastrozole, tamoxifen alone and in combination on plasma lipids and 
bone-derived resorption during neoadjuvant therapy in the impact trial. Annals of Oncology 16(10): 1632-1638.

Bashkaran, K., Zunaina, E., Bakiah, S., Sulaiman, S.A., Sirajudeen, K. \& Naik, V. 2011. Anti-inflammatory and antioxidant effects of Tualang honey in alkali injury on the eyes of rabbits: Experimental animal study. $B M C$ Complementary and Alternative Medicine 11: 90.

Benzie, I.F.F. \& Strain, J.J. 1999. Ferric reducing/antioxidant power assay: Direct measure of total antioxidant activity of biological fluids and modified version for simultaneous measurement of total antioxidant power and ascorbic acid concentration. Methods in Enzymology 299: 15-27.

Beretta, G., Granata, P., Ferrero, M., Orioli, M. \& Facino, R.M. 2005. Standardization of antioxidant properties of honey by a combination of spectrophotometric/fluorimetric assays and chemometrics. Analytica Chimica Acta 533(2): 185-191.

Bertoncelj, J., Doberšek, U., Jamnik, M. \& Golob, T. 2007. Evaluation of the phenolic content, antioxidant activity and colour of Slovenian honey. Food Chemistry 105(2): 822-828.

Bogdanov, S. 2011. Honey composition. In The Book of Honey. Switzerland: Bee Product Science. pp. 1-11.

Bogdanov, S. 2009. Harmonised Methods of the International Honey Commission. Germany: International Honey Commission. pp. 1-63.

Bonjour, J.P., Benoit, V., Payen, F. \& Kraenzlin, M. 2013. Consumption of yogurts fortified in vitamin $\mathrm{D}$ and calcium reduces serum parathyroid hormone and markers of bone resorption: A double-blind randomized controlled trial in institutionalized elderly women. The Journal of Clinical Endocrinology \& Metabolism 98(7): 2915-2921.

Bray, F., Ferlay, J., Soerjomataram, I., Siegel, R.L., Torre, L.A. \& Jemal, A. 2018. Global cancer statistics 2018: GLOBOCAN estimates of incidence and mortality worldwide for 36 cancers in 185 countries. A Cancer Journal for Clinicians 68(6): 394-424.

Bromann, P.A., Korkaya, H. \& Courtneidge, S.A. 2004. The interplay between Src family kinases and receptor tyrosine kinases. Oncogene 23(48): 7957-7968.

Candiracci, M., Piatti, E., Dominguez-Barragán, M., GarcíaAntrás, D., Morgado, B., Ruano, D., Gutiérrez, J.F., Parrado, J. \& Castaño, A.I. 2012. Anti-inflammatory activity of a honey flavonoid extract on lipopolysaccharide-activated N13 microglial cells. Journal of Agricultural and Food Chemistry 60(50): 12304-12311.

Cho, H., Yun, C.W., Park, W.K., Kong, J.Y., Kim, K.S., Park, Y., Lee, S. \& Kim, B.K. 2004. Modulation of the activity of pro-inflammatory enzymes, COX-2 and iNOS, by chrysin derivatives. Pharmacological Research 49(1): 37-43.

Codex Alimentarius Commission. 1982. Revised Codex Standard for Honey 1987, 2001. Geneva: Codex Standards. pp. 1-8.

Dauvois, S., White, R. \& Parker, M.G. 1993. The antiestrogen ICI 182780 disrupts estrogen receptor nucleocytoplasmic shuttling. Journal of Cell Science 106(4): 1377-1388.
Duan, W., Shen, X., Lei, J., Xu, Q., Yu, Y., Li, R., Wu, E. \& Ma, Q. 2014. Hyperglycemia, a neglected factor during cancer progression. BioMed Research International 2014: Article ID. 461917.

Eastell, R., Hannon, R.A., Cuzick, J., Dowsett, M., Clack, G. \& Adams, J.E. 2006. Effect of an aromatase inhibitor on BMD and bone turnover markers: 2-Year results of the anastrozole, tamoxifen, alone or in combination (ATAC) trial (18233230). Journal of Bone and Mineral Research 21(8): 1215-1223.

Fauzi, A.N., Norazmi, M.N. \& Yaacob, N.S. 2011. Tualang honey induces apoptosis and disrupts the mitochondrial membrane potential of human breast and cervical cancer cell lines. Food and Chemical Toxicology 49(4): 871-878.

Ferlay, J., Soerjomataram, I., Dikshit, R., Eser, S., Mathers, C., Rebelo, M., Parkin, D.M., Forman, D. \& Bray, F. 2015. Cancer incidence and mortality worldwide: Sources, methods and major patterns in GLOBOCAN 2012. International Journal of Cancer 136(5): E359-E386.

Finn, R.S. 2008. Targeting Src in breast cancer. Annals of Oncology 19(8): 1379-1386.

Galal, R.M., Zaki, H.F., Seif El-Nasr, M.M. \& Agha, A.M. 2012. Potential protective effect of honey against paracetamol-induced hepatotoxicity. Archives of Iranian Medicine 15(11): 674-680.

Garcia, R., Bowman, T.L., Niu, G., Yu, H., Minton, S., MuroCacho, C.A., Cox, C.E., Falcone, R., Fairclough, R., Parsons, S., Laudano, A., Gazit, A., Levitzki, A., Kraker, A. \& Jove, R. 2001. Constitutive activation of Stat3 by the Src and JAK tyrosine kinases participates in growth regulation of human breast carcinoma cells. Oncogene 20(20): 2499-2513.

García-Tuñón, I., Ricote, M., Ruiz, A., Fraile, B., Paniagua, R. \& Royuela, M. 2006. Role of tumor necrosis factor- $\alpha$ and its receptors in human benign breast lesions and tumors (in situ and infiltrative). Cancer Science 97(10): 1044-1049.

Ghazali, W.S.W., Romli, A.C. \& Mohamed, M. 2017. Effects of honey supplementation on inflammatory markers among chronic smokers: A randomized controlled trial. BMC Complementary and Alternative Medicine 17(175): 1-6.

Grimm, S.W. \& Dyroff, M.C. 1997. Inhibition of human drug metabolizing cytochromes P450 by anastrozole, a potent and selective inhibitor of aromatase. Drug Metabolism and Disposition 25(5): 598-602.

Gruber, C.J., Tschugguel, W., Schneeberger, C. \& Huber, J.C. 2002. Production and actions of estrogens. New England Journal of Medicine 346(5): 340-352.

Hazirah, H., Yasmin Anum, M.Y. \& Norwahidah, A.K. 2019. Antioxidant properties of stingless bee honey and its effect on the viability of lymphoblastoid cell line. Medicine \& Health 14(1): 91-105.

Henderson, I.C. 1991. Endocrine therapy of metastatic breast cancer. Breast Diseases 2: 559-603.

Huang, M.H., Huang, S.S., Wang, B.S., Wu, C.H., Sheu, M.J., Hou, W.C., Lin, S.S. \& Huang, G.J. 2011. Antioxidant 
and anti-inflammatory properties of Cardiospermum halicacabum and its reference compounds ex vivo and in vivo. Journal of Ethnopharmacology 133(2): 743-750.

Hughes, F.J., Buttery, L.D., Hukkanen, M.V., O’Donnell, A., Maclouf, J. \& Polak, J.M. 1999. Cytokine-induced prostaglandin E2 synthesis and cyclooxygenase-2 activity are regulated both by a nitric oxide-dependent andindependent mechanism in rat osteoblasts in vitro. Journal of Biological Chemistry 274(3): 1776-1782.

Husniati, Y.L., Hazlina, N.H.N., Azidah, A.K., Norhayati, M.N., Amrah, S.S., Idiana, H.I., Bahari, I.S., Juhara, H. \& Imran, M.K. 2013. Safety of honey in postmenopausal women. International Medical Journal 20(1): 25-28.

Hussain, N.H.N., Sulaiman, S.A., Idiana Hassan, I., Abdul Kadir, A., Mohd Nor, N., Bahari Ismail, S., Yaacob, L.H., Zakaria, R., Shaniza Shafie, N., Haron, J. \& Imran Musa, K. 2012. Randomized controlled trial on the effects of Tualang honey and hormonal replacement therapy (HRT) on cardiovascular risk factors, hormonal profiles and bone density among postmenopausal women: A pilot study. Journal of Food Research 1(2): 171-188.

Hussein, S.Z., Mohd Yusoff, K., Makpol, S. \& Mohd Yusoff, Y.A. 2012. Gelam honey inhibits the production of proinflammatory, mediators NO, PGE 2, TNF- $\alpha$, and IL-6 in carrageenan-induced acute paw edema in rats. EvidenceBased Complementary and Alternative Medicine 2012: Article ID. 109636.

Jaganathan, S.K. \& Mandal, M. 2009. Antiproliferative effects of honey and of its polyphenols: A review. Journal of Biomedicine and Biotechnology 2009: 830616.

Kaur, R.P., Rubal, Banipal, R.P.S., Vashistha, R., Dhiman, M. \& Munshi, A. 2019. Association of elevated levels of C-reactive protein with breast cancer, breast cancer subtypes, and poor outcome. Current Problems in Cancer 43(2): 123129.

Kenny, A. \& Raisz, L. 2002. Mechanism of bone remodeling: Implications for clinical practice. The Journal of Reproductive Medicine 47(Supplement 1): 63-70.

Khalil, M.I., Mohamed, M., Jamalullail, S.M.S.S., Alam, N. \& Sulaiman, S.A. 2011. Evaluation of radical scavenging activity and colour intensity of nine Malaysian honeys of different origin. Journal of ApiProduct and ApiMedical Science 3(1): 4-11.

Kishore, R.K., Halim, A.S., Syazana, M.S.N. \& Sirajudeen, K.N.S. 2011. Tualang honey has higher phenolic content and greater radical scavenging activity compared with other honey sources. Nutrition Research 31(4): 322-325.

Kozłowski, L., Zakrzewska, I., Tokajuk, P. \& Wojtukiewicz, M.Z. 2003. Concentration of interleukin-6 (IL-6), interleukin-8 (IL-8) and interleukin-10 (IL-10) in blood serum of breast cancer patients. Roczniki Akademii Medycznej Bialymstoku 48: 82-84.

Leu, C.M., Wong, F.H., Chang, C., Huang, S.F. \& Hu, C. 2003. Interleukin-6 acts as an antiapoptotic factor in human esophageal carcinoma cells through the activation of both
STAT3 and mitogen-activated protein kinase pathways Oncogene 22: 7809-7818.

Lim, V.W., Li, J., Gong, Y., Jin, A., Yuan, J.M., Yong, E.L. \& Koh, W.P. 2014. Serum estrogen receptor bioactivity and breast cancer risk among postmenopausal women. Endocrinerelated Cancer 21(2): 263-273.

Litherland, S. \& Jackson, I.M. 1988. Antioestrogens in the management of hormone- dependent cancer. Cancer Treatment Reviews 15(3): 183-194.

Liu, L., Mills, P.J., Rissling, M., Fiorentino, L., Natarajan, L., Dimsdale, J.E., Sadler, G.R., Parker, B.A. \& Ancoli-Israel, S. 2012. Fatigue and sleep quality are associated with changes in inflammatory markers in breast cancer patients undergoing chemotherapy. Brain, Behavior, and Immunity 26(5): 706-713

Looker, A.C., Bauer, D.C., Chestnut III, C.H., Gundberg, C.M., Hochberg, M.C., Klee, G., Kleerekoper, M., Watts, N.B. $\&$ Bell, N.H. 2000. Clinical use of biochemical markers of bone remodeling: Current status and future directions. Osteoporosis International 11(6): 467-480.

Love, R.R., Barden, H.S., Mazess, R.B., Epstein, S. \& Chappell, R.J. 1994. Effect of tamoxifen on lumbar spine bone mneral density in postmenopausal women after 5 years. Archives of Internal Medicine 154(22): 2585-2588.

Love, R.R., Mazess, R.B., Barden, H.S., Epstein, S., Newcomb, P.A., Jordan, V.C., Carbone, P.P. \& DeMets, D.L. 1992. Effects of tamoxifen on bone mineral density in postmenopausal women with breast cancer. New England Journal of Medicine 326(13): 852-856.

Manolagas, S.C., Kousteni, S. \& Jilka, R.L. 2002. Sex steroids and bone. Recent Progress in Hormone Research 57: $385-$ 409.

Mettler, L., Salmassi, A., Heyer, M., Schmutzier, A., Schollmeyer, T. \& Jonat, W. 2004. Perioperative levels of interleukin1 beta and interleukin-6 in women with breast cancer. Clinical and Experimental Obstetrics \& Gynecology 31(1): 20-22.

Miles, D., Happerfield, L., Naylor, M., Bobrow, L., Rubens, R. \& Balkwwill, F. 1994. Expression of tumour necrosis factor $(\mathrm{TNF} \alpha)$ and its receptors in benign and malignant breast tissue. International Journal of Cancer 56(6): 777-782.

Miller, L.J., Kurtzman, S.H., Anderson, K., Wang, Y., Stankus, M., Renna, M., Lindquist, R., Barrows, G. \& Kreutzer, D.L. 2000. Interleukin-1 family expression in human breast cancer: Interleukin-1 receptor antagonist. Cancer Investigation 18(4): 293-302.

Mohamed, M., Sirajudeen, K.N.S., Swamy, M., Yaacob, N.S. \& Sulaiman, S.A. 2010. Studies on the antioxidant properties of Tualang honey of Malaysia. African Journal of Traditional, Complementary and Alternative Medicines 7(1): 59-63.

Nabholtz, J.M., Buzdar, A., Pollak, M., Harwin, W., Burton, G., Mangalik, A., Steinberg, M., Webster, A. \& Von Euler, M. 2000. Anastrozole is superior to tamoxifen as first-line therapy for advanced breast cancer in postmenopausal women: Results of a North American multicenter 
randomized trial. Journal of Clinical Oncology 18(22): 3758-3767.

Nicolini, A., Carpi, A. \& Rossi, G. 2006. Cytokines in breast cancer. Cytokine \& Growth Factor Reviews 17(5): 325-337.

Osborne, C.K. \& Schiff, R. 2011. Mechanisms of endocrine resistance in breast cancer. Annual Review of Medicine 62: 233-247.

Pantschenko, A.G., Pushkar, I., Anderson, K.H., Wang, Y., Miller, L.J., Kurtzman, S.H., Barrows, G. \& Kreutzer, D.L. 2003. The interleukin-1 family of cytokines and receptors in human breast cancer: Implications for tumor progression. International Journal of Oncology 23(2): 269-284.

Pfeilschifter, J., Köditz, R., Pfohl, M. \& Schatz, H. 2002. Changes in proinflammatory cytokine activity after menopause. Endocrine Reviews 23(1): 90-119.

Philip, M., Rowley, D.A. \& Schreiber, H. 2004. Inflammation as a tumor promoter in cancer induction. Seminars in Cancer Biology 14(6): 433-439.

Pierce, B.L., Ballard-Barbash, R., Bernstein, L., Baumgartner, R.N., Neuhouser, M.L., Wener, M.H., Baumgartner, K.B., Gilliland, F.D., Sorensen, B.E., McTiernan, A. \& Ulrich, C.M. 2009. Elevated biomarkers of inflammation are associated with reduced survival among breast cancer patients. Journal of Clinical Oncology 27(21): 3437-3444.

Playford, M.P. \& Schaller, M.D. 2004. The interplay between Src and intergrins in normal and tumor biology. Oncogene 23: 7928-7946.

Ravishankaran, P. \& Karunanithi, R. 2011. Clinical significance of preoperative serum interleukin-6 and C-reactive protein level in breast cancer patients. World Journal of Surgical Oncology 9(1): 18.

Reddy, S.V. \& Roodman, G.D. 1998. Control of osteoclast differentiation. Critical Reviews in Eukaryotic Gene Expression 8(1): 1-17.

Riggs, B.L., Khosla, S. \& Melton III, L.J. 2002. Sex steroids and the construction and conservation of the adult skeleton. Endocrine Reviews 23(3): 279-302.

Rogers, A., Saleh, G., Hannon, R.A., Greenfield, D. \& Eastell, R. 2002. Circulating estradiol and osteoprotegerin as determinants of bone turnover and bone density in postmenopausal women. Journal of Clinical Endocrinology and Metabolism 87(10): 4470-4475.

Rosell, J., Nordenskjöld, B., Bengtsson, N.O., Fornander, T., Hatschek, T., Lindman, H., Malmström, P.O., Wallgren, A., Stål, O. \& Carstensen, J. 2017. Long-term effects on the incidence of second primary cancers in a randomized trial of two and five years of adjuvant tamoxifen. Acta Oncologica 56(4): 614-617.

Russo, J. \& Russo, I.H. 2006. The role of estrogen in the initiation of breast cancer. The Journal of Steroid Biochemistry and Molecular Biology 102(1-5): 89-96.

Saba, Z.H., Suzana, M. \& Yasmin Anum, M.Y. 2013. Honey: Food or medicine? Medicine \& Health 8(1): 3-18.

Sheen-Chen, S.M., Chen, W.J., Eng, H.L. \& Chou, F.F. 1997. Serum concentration of tumor necrosis factor in patients with breast cancer. Breast Cancer Research and Treatment 43(3): 211-215.

Siegel, R.L., Miller, K.D. \& Jemal, A. 2019. Cancer statistics. A Cancer Journal for Clinicians 69(1): 7-34.

Singleton, V.L., Orthofer, R. \& Lamuela-Raventós, R.M. 1999. Analysis of total phenols and other oxidation substrates and antioxidants by means of folin-ciocalteu reagent. Methods in Enzymology 299: 152-178.

Socha, R., Juszczak, L., Pietrzyk, S. \& Fortuna, T. 2009. Antioxidant activity and phenolic composition of herb honeys. Food Chemistry 113(2): 568-574.

Tartibian, B. \& Maleki, B.H. 2012. The effects of honey supplementation on seminal plasma cytokines, oxidative stress biomarkers, and antioxidants during 8 weeks of intensive cycling training. Journal of Andrology 33(3): 449-461.

Tsiapara, A.V., Jaakkola, M., Chinou, I., Graikou, K., Tolonen, T., Virtanen, V. \& Moutsatsou, P. 2009. Bioactivity of Greek honey extracts on breast cancer (MCF-7), prostate cancer (PC-3) and endometrial cancer (Ishikawa) cells: Profile analysis of extracts. Food Chemistry 116(3): 702-708.

Tushar, T., Vinod, T., Rajan, S., Shashindran, C. \& Adithan, C. 2007. Effect of honey on CYP3A4, CYP2D6 and CYP2C19 enzyme activity in healthy human volunteers. Basic \& Clinical Pharmacology \& Toxicology 100(4): 269-272.

Vasikaran, S., Eastell, R., Bruyère, O., Foldes, A.J., Garnero, P., Griesmacher, A., McClung, M., Morris, H.A., Silverman, S., Trenti, T., Wahl, D.A., Cooper, C. \& Kanis, J.A. 2011. Markers of bone turnover for the prediction of fracture risk and monitoring of osteoporosis treatment: A need for international reference standards. Osteoporosis International 22(2): 391-420.

Wattel, A., Kamel, S., Mentaverri, R., Lorget, F., Prouillet, C., Petit, J.P., Fardelonne, P. \& Brazier, M. 2003. Potent inhibitory effect of naturally occurring flavonoids quercetin and kaempferol on in vitro osteoclastic bone resorption. Biochemical Pharmacology 65(1): 35-42.

Wheater, G., Elshahaly, M., Tuck, S.P., Datta, H.K. \& Van Laar, J.M. 2013. The clinical utility of bone marker measurements in osteoporosis. Journal of Translational Medicine 29(11): 201.

Yaacob, N.S., Nengsih, A. \& Norazmi, M.N. 2013. Tualang honey promotes apoptotic cell death induced by tamoxifen in breast cancer cell lines. Evidence-Based Complementary and Alternative Medicine 2013: 989841.

Yaghoobi, N., Al-Waili, N., Ghayour-Mobarhan, M., Parizadeh, S., Abasalti, Z., Yaghoobi, Z., Yaghoobi, F. \& Esmaeili, H. 2008. Natural honey and cardiovascular risk factors; effects on blood glucose, cholesterol, triacylglycerole, CRP, and body weight compared with sucrose. The Scientific World Journal 8: 463-469.

Yun, K.J., Kim, J.Y., Kim, J.B., Lee, K.W., Jeong, S.Y., Park, H.J., Jung, H.J., Cho, Y.W., Yun, K. \& Lee, K.T. 2008. Inhibition of LPS-induced NO and PGE 2 production by asiatic 
acid via NF- $\mathrm{B}$ inactivation in RAW 264.7 macrophages: Possible involvement of the IKK and MAPK pathways. International Immunopharmacology 8(3): 431-441.

Zaid, S., Sulaiman, S., Othman, N., Soelaiman, I., Shuid, A., Mohamad, N. \& Muhamad, N. 2012. Protective effects of Tualang honey on bone structure in experimental postmenopausal rats. Clinics 67(7): 779-784.

Zaid, S.S.M., Sulaiman, S.A., Sirajudeen, K.N.M. \& Othman, N.H. 2010. The effects of Tualang honey on female reproductive organs, tibia bone and hormonal profile in ovariectomised rats - animal model for menopause. $B M C$ Complementary and Alternative Medicine 10(1): 82.

Zakaria, Z., Zainal Abidin, Z.F., Gan, S.H., Wan Abdul Hamid, W.Z. \& Mohamed, M. 2018. Effects of honey supplementation on safety profiles among postmenopausal breast cancer patients. Journal of Taibah University Medical Sciences 13(6): 535-540.
Zaida Zakaria \& Mahaneem Mohamed*

Department of Physiology

School of Medical Sciences

Universiti Sains Malaysia

16150 Kubang Kerian, Kelantan Darul Naim

Malaysia

Wan Zuraida Wan Ab Hamid

Department of Immunology

School of Medical Sciences

Universiti Sains Malaysia

16150 Kubang Kerian, Kelantan Darul Naim

Malaysia

*Corresponding author; email: mahaneem@usm.my

Received: 14 December 2019

Accepted: 27 November 2020 